\title{
LONG-TERM CARE INSTITUTIONS FOR ELDERS AND THE HEALTH SYSTEM
}

\author{
Marion Creutzberg ${ }^{1}$ \\ Lúcia Hisako Takase Gonçalves ${ }^{2}$ \\ Emil Albert Sobottka ${ }^{3}$ \\ Beatriz Sebben Ojeda ${ }^{4}$
}

Creutzberg M, Gonçalves LHT, Sobottka EA, Ojeda BS. Long-term care institutions for elders and the health system. Rev Latino-am Enfermagem 2007 novembro-dezembro; 15(6):1144-9.

Objective: Analyze Long Term Care Institutions for Elders (ILPI) organizational social system and its relation to the National Health System (SUS). To identify communication that occurs in the structural couplings between the ILPIS and the SUS and to analyze resonances of the structural coupling between the SUS and the ILPIs. Method: A descriptive, exploratory qualitative study using the functional Niklas Luhmann's method. The data were collected using second order observations, through interviews with seven managers and eight elders, communication analysis of 52 Brazilian ILPIs and third order observations in national literature. Results: The exclusion of the institutionalized elder from the programmed health actions occurs in the health system. There is mutual lack of knowledge between the ILPIS and SUS, and stimulus is necessary for a more successful structural coupling. Conclusions: The little sensitiveness of the SUS regarding the ILPI communications was identified as impediment to the performance of these institutions' social function.

DESCRIPTORS: homes for the aged; institutionalization; aged; geriatrics; systems theory

\section{LA INSTITUCIÓN DE LARGA PERMANENCIA PARA ANCIANOS Y EL SISTEMA DE SALUD}

Objetivos: Analizar el sistema social organizacional Institución de Larga Permanencia para Ancianos (ILPI) y su relación con el Sistema de Salud (SUS). Identificar las comunicaciones que ocurren en los acoplamientos estructurales entre la ILPI y el SUS. Analizar las repercusiones del acoplamiento estructural en la ILPI. Método: Estudio exploratorio descriptivo, cualitativo, con la utilización del método funcional de Niklas Luhmann. La recolecta de datos utilizó observaciones de segundo orden, a través de entrevistas con 7 dirigentes y 8 ancianos, análisis de comunicaciones de 52 ILPIs brasileñas y observaciones de tercer orden en literatura nacional. Resultados: En el sistema de salud ocurre la exclusión del anciano institucionalizado de las acciones programáticas en la salud. Hay un desconocimiento recíproco entre ILPIs y SUS, necesitando estímulos para un acoplamiento estructural más exitoso. Conclusiones: La diminuta sensibilidad del Sistema de Salud a las comunicaciones de la ILPI fue identificada como un obstáculo en el desempeño de la función social de esas instituciones.

DESCRIPTORES: hogares para ancianos; institucionalización; anciano; geriatría; teoría de sistemas

\section{A INSTITUIÇÃO DE LONGA PERMANÊNCIA PARA IDOSOS E O SISTEMA DE SAÚDE}

Objetivos: Analisar o sistema social organizacional Instituição de Longa Permanência para Idosos (ILPI) e sua relação com o Sistema Único de Saúde (SUS). Identificar as comunicações que ocorrem nos acoplamentos estruturais entre a ILPI e o SUS. Analisar as ressonâncias do acoplamento estrutural com o SUS, na ILPI. Método: Estudo exploratório descritivo, qualitativo, com uso do método funcional de Niklas Luhmann. A coleta de dados utilizou observações de segunda ordem, por meio de entrevistas com 7 dirigentes e 8 idosos, análise de comunicações de 52 ILPIs brasileiras sem fins lucrativos, de caráter público ou privado e observações de terceira ordem em literatura nacional. Resultados: No sistema de saúde ocorre a exclusão do idoso institucionalizado das ações programáticas em saúde. Há desconhecimento mútuo entre ILPIs e SUS, necessitando estimulação para um acoplamento estrutural mais bem sucedido. Conclusões: A diminuta sensibilidade do Sistema de Saúde às comunicações da ILPI foi identificada como entrave no desempenho da função social dessas instituições.

DESCRITORES: instituição de longa permanência para idosos; institucionalização; idoso; geriatria; teoria de sistemas

\footnotetext{
${ }^{1}$ RN, PhD in Biomedical Gerontology, Adjunct Professor, Rio Grande do Sul Pontifícia Universidade Católica, College of Nursing, Nutrition and Physioterapy, Brazil, email: marionc@pucrs.br; ${ }^{2}$ RN, PhD in Nursing, Full Professor, Santa Catarina Federal University, Brazil, e-mail: Itakase@brturbo.com.br; ${ }^{3}$ Sociologist, PhD in Sociology, Adjunct Professor, Rio Grande do Sul Pontifícia Universidade Católica, College of Philosophy and Human Sciences, Brazil, e-mail: sobottka@pucrs.br; ${ }^{4}$ RN, PhD in Psychology, Adjunct Professor, Rio Grande do Sul Pontifícia Universidade Católica, College of Nursing, Nutrition and Physioterapy, Brazil, e-mail: santoslara@pucrs.br
} 


\section{INTRODUCTION}

$\boldsymbol{R}$ isk factors for institutionalization comprise several factors; for instance, the increase in the number of impaired and frail elderly in Brazilian capitals, the reduction in the availability of family care and intergenerational transfers in the urban context, the inexistence of social and health support services, in addition to the high cost of home care, homes with reduced spaces and structures that increase the risk of falls, as well as any violence against elderly. Research shows that the number of elderly living in Long Term Care Institutions for the Elderly (LTIEs) in countries with advanced demographic transition reaches $11 \%$, while less than $1.5 \%$ in Brazil $^{1}$. The tendency is for an increase in LTIEs in Brazil, despite the fact that policies prioritize the family as responsible for the elderly's care. Though imbued with this perception, there is a consensus that LTIEs are often an important alternative, a voluntary and expected choice that should guarantee quality of life.

The LTIE is considered an organizational social system. The societal complexity of functionally differentiated societies led to an outburst of organizations to develop activities restricted to achieving and fulfilling specific goals and many human needs, in addition to developing a social function. Considering LTIEs, goals regard care for elderly "without family bonds or conditions to provide for their own subsistence in a way that meets their needs regarding housing, feeding, health and social life" or "socially vulnerable dependent and/or independent elderly"(2). The complexity that led to LTIEs' functional differentiation is the existence of elderly in these conditions, as well as the multiplicity of related factors.

The LTIE issue is a chronic problem, particularly when considering institutions for lowincome elderly, which apparently has no solution in the Brazilian society. However, as previously stated in other studies, it is believed that "institutions are subject to influences and reformulations"(3).

The Brazilian National Elderly Policy (NEP) ${ }^{(2)}$ implies the creation and implementation of multiple and varied actions and services, considering the interand intra-social articulation of non-governmental organizations and every social segment. However, difficulties are observed to make these proposals operational and implement them at the local level, regarding LTIEs and the health system as well.
The analysis of the LTIEs-health system relationship was performed by means of Niklas Luhmann's analytical-explanatory framework ${ }^{(4)}$, an updated formulation of Systems Theory, with applications in social and cultural phenomena using an interdisciplinary approach. Organizational social systems like LTIEs can be analyzed in terms of their internal processes, as well as the interdependencies with other systems. The health system is guided by the surroundings and, thus, determined by what it observes in the environment. The system's internal communications and programs mainly regard human health-illness conditions that mobilize resources and generate a health system usage cycle. When differentiated as a system, health acquires a historically constructed body of knowledge and regulations, which includes specific knowledge and regulations of the various health professions ${ }^{(5)}$.

In Brazil, the Single Health System (SHS) [Sistema Único de Saúde -SUS] resulted from reflexive processes that culminated in the framework for new health policies and practices, the $8^{\text {th }}$ National Health Conference, held in 1986. This Conference offered support to turn the SHS legally legitimate and implement it in the 1988 Constitution and in the respective legislation issued in 1990 . The health care model that grounds SHS actions is based on the guidelines for decentralization, integral care with priority on preventive actions, health care actions that do not cause harm, and with community participation. Besides interdisciplinary knowledge and intersectorial work, intervention strategies comprise actions for health promotion and maintenance, risk and damage prevention, cure, recovery and rehabilitation, directed at patients, families, communities or groups, from a health surveillance perspective ${ }^{(6)}$. In this sense, it is clear that the Brazilian Health System has advanced. Nonetheless, a long road lies ahead for the comprehensive implementation of the SHS policy in every dimension, and which "blends in a new episteme in the universe of social, political, economic, cultural, ecological, biological and physical-chemical relationships" ${ }^{\prime \prime 5}$. It is this context the study on LTIE in relation to the health system is inserted in.

\section{OBJECTIVES}

To analyze LTIEs' organizational system and their relation with the health system, identifying the 
communications that occur in structural connections between LTIEs and the health system, as well as the resonance of those connections in the LTIE.

\section{METHOD}

This is a qualitative, exploratory-descriptive study, which used Luhmann's Systems Theory, named functional method, as the analytical method ${ }^{(4)}$.

The main focus was LTIEs, within the Brazilian context, in the urban environment, with inhabitants who lacked conditions to provide for their own subsistence, or originating from low-income families. The study comprised institutions regularly referred to as LTIEs (traditionally known as nursing homes), which are public or private non-for-profit organizations.

The diverse observations provide a better understanding of the problem. From this perspective, data were collected through second- and third-order observations $^{(4)}$. Second-order observation regards self-observation of the system. It is important because the observed system may have latent functions, which are not self-noticed, but can be understood by the researcher. This observation was performed through interviews with seven directors of different internal LTIE subsystems, and eight elderly living in three LTIEs in the metropolitan region of Porto Alegre (Southern Brazil). Considering the diverse viewpoints regarding the issue and the events presented under different circumstances, the communications produced by 52 LTIEs, broadcasted by the media, were observed. The referred material expresses internal operations, representing how organizations see themselves. It also expresses the social environment's expectations of the organization.

Third-order observation refers to the researcher's observation of the artistic and literary production, which assigns themes to social systems' self-observation. The investigations, particularly descriptive ones, are regarded as important sources for this observation. Twenty-eight national publications were observed. The publications were located using a database survey, considering the period 1998-2004, through the descriptors: shelter/home, nursing home, and institutionalization.
Niklas Luhmann's functional analysis method was the framework used for data analysis of secondand third-order observations. Content Analysis( ${ }^{(7)}$ was the method used to analyze the text material, obtained by transcribing the interviews, as well as from the printed compilation of LTIEs' communications. The analysis consisted in a triangulation of the data obtained from the diverse sources; that is, elderly, directors, LTIEs, literature and legislation, in addition to the researcher's experience. This comprised the data validation procedure.

The study was approved by the Ethics Committee at the Pontifical Catholic University of Rio Grande do Sul (PUCRS. LTIE directors and elderly residents provided written consent, and the organizations' identities were preserved.

\section{DATA PRESENTATION AND ANALYSIS}

Directors first acknowledge the relationship between LTIEs and the health system through the supervision by the National Health Surveillance agency, responsible for issuing and renovating LTIEs' licenses and Permissions to Operate. Authors ${ }^{(8)}$ have appointed the need for a more systematic supervision of LTIEs' structure and work. According to the Technical Regulation approved by the National Health Surveillance Agency ${ }^{(9)}$ [Agência Nacional de Vigilância Sanitária], health departments should systematically measure the specific indicators used for LTIE evaluation, such as annual mortality rate, incidence density of acute diarrheic disease and scabies, prevalence of elderly with diabetes mellitus and dementia, and the rate of health care provided to LTIE employees. It was observed that supervision is an important health system encouragement*, causing resonances in institutions.

Among the internal LTIE subsystems, there is a need, determined by law, for the team to become involved with the healthcare processes, and see to everyday care demands. Nevertheless, the relationship with healthcare services is inevitable, since there is often a need for diagnostic exams and forwarding to specialties or hospitalization. In general, elderly are only transferred to health services in case of changes in their health conditions ${ }^{(10-11)}$, as stated by one woman:

* Luhmann uses the term "irritation". From the perspective of social dynamics, irritation is an information that disturbs, stimulates a reaction in the system. Without reaction, there is no active information. 
The health issue is well covered, because, if there is something they cannot solve here, they send us to a health unit (I5).

The LTIE is involved in the whole process, despite asking and obtaining, upon the elderly's admission, commitment from the family or responsible to follow these situations.

Regarding the health system, three tendencies were observed: in public LTIEs, health care is obtained exclusively from public health services; at philanthropic LTIEs, the SHS network is used and, in other cases, to avoid the difficulties they perceive in this relationship, the institution establishes partnerships with private services or uses the services covered by the elderly's private health insurance. The latter is less common, since only few elderly actually have a private health insurance. A study ${ }^{(12)}$ has identified that $100 \%$ of elderly from two LTIEs, and $96 \%$ from another institution did not have a health insurance. It was confirmed in other studies ${ }^{(10)}$ that the availability of healthcare services for elderly, at the different levels, mostly depends on LTIE directors and internal health teams' concept and knowledge regarding the elderly's health, from a gerontological perspective. Health care, in general, is centered on cure and rehabilitation, which opposes the current Brazilian Health System's guidelines and health policies for elderly. These institutions rarely promote systematic health promotion programs and health education activities with a view to maintaining functional capacity.

The relationship with basic healthcare services

The directors stated that, apparently, basic healthcare services do not acknowledge the LTIE as belonging to the geographical area they cover:

... they [health service] say it [health] is the institution's problem (D1).

Elderly are not considered residents of that area:

They are not concerned with our elderly, they think the elderly are not part of this community (D1).

In addition, [City Administration] does not include LTIE residents in Family Health, Mental Health and Oral Health Programs (LTIE11).

Access to healthcare is marked by disconnections because, according to the directors:

... services do not make it easier, everything is complicated, we have to go from one unit to another (D1).
It appears that health services believe that, since the LTIE has a health team, it should see to their health care needs. This generates discontent in LTIEs, as a resonance:

... we have to do everything, take care of them, check their medication, we have to see to it (D1).

In general, the LTIE health team is responsible for the initial identification of the need to forward elderly to diagnostic services and specialties. At that moment, the institution follows the regular system of the local service. Despite mandatory preferential care to elderly in health departments ${ }^{(2)}$, discrimination, as well as the lack of humanization in relationships with professionals in this area were previously observed elsewhere ${ }^{(13-14)}$. Interviewees report the barriers and condition of double discrimination of institutionalized elderly:

Regarding health services, they lack specific care, alternatives for elderly healthcare. If the elderly is unable to arrive and run to the front of the line in the health unit, people simply run over him, so it is impossible for him to get a form. They often complain about that. (D6)

One LTIE complaint regards the access difficulty to the elderly's medication, which is their right by $\operatorname{law}^{(2)}$ :

... what is really difficult on us is the medication that we are unable to get at the health unit (D4).

In order to obtain the medication at basic healthcare services, a personal register is made, which, in addition to making it possible to follow the individual, permits to appropriately foresee the medication needed in order to meet the unit's demands. Directors consider this a problem, which implies their lack of knowledge regarding health service management.

Regarding elderly vaccination campaigns, with the anti-influenza vaccine, Basic Health Units joined efforts to reach every elderly in their area, including LTIE residents.

The health teams have sought and established an approximation to basic healthcare services through dialogues and negotiations. Despite the advancements, it remains evident that LTIE elderly are not considered when counting community residents. For instance, directors stated that the material resources for controlling diabetics are not forwarded to the LTIE to administer. In order to forward that material, the health service, based on the guidelines for Hypertension and Diabetes Mellitus Health Care, must obtain information from the elderly 
and follow them individually. In this case, collaborative action between the health service and the LTIE is needed. The institution can, with the work of its internal team, perform what is foreseen in the program action of providing the health service with the data, guaranteeing its productivity in that area. These alternatives would find the necessary encouragement in the National Elderly Health Policy.

The relationship with specialized and hospital services

A frequent need was observed to forward elderly to emergency healthcare services or hospitalization. Directors expressed the relationship with the city's patient transportation service (SAMU) and other negotiation to better meet this need:

We have a very good relationship with SAMU, so we call them or we take the elderly ourselves (D3).

In addition to the municipal ambulance and patient transportation service, some LTIEs, or elderly - personally - have agreements with private companies. With a view to avoiding long waits to schedule diagnostic exams, LTIEs establish partnerships with private specialized services.

The number of elderly hospitalizations in Brazil is rather high, with more beds being used, for more days, as well as high re-hospitalization rates ${ }^{(15)}$. No accurate data were found regarding the hospitalization rates of institutionalized elderly.

There are difficulties regarding emergency or hospitalization services, involving disrespect toward elderly as well as not giving them priority:

For the hospital, the elderly is just someone who will use another bed, what will (s)he give back? Expenses, work, that is so true that they come back with pressure ulcers. It's complicated (D1).

One explanation for this situation is the discussion about age and the allocation of scarce resources. Elderly have an advantage in merit criteria, but not in the criteria based on need and prognosis, used to dispute the availability of healthcare resources. Moreover, considering the LTIEs' image in the societal environment, it is inferred that institutionalized elderly are twice as excluded in this process. In order to change the condition of being assigned a secondary position in health care, this population group and society will need great encouragement for the complete implementation of policies that promote their inclusion.

Regarding hospitalization, another aspect evidenced, internal to the LTIE, was the conflict regarding the decision of hospitalization. It is observed that, on the one hand, there is pressure towards hospitalization but, on the other, there is resistance:

So there is the following criticism: the elderly must go to the hospital. If that elderly dies in transport, we are criticized: why did you send him to the hospital? (D1)

The decision regarding hospitalization or forwarding to specialized care should be associated with clarity concerning the human and material resources available at the LTIE. A simple dialogue between team members, with a view to clarifying and reaching a consensus, could minimize these conflicts. Nevertheless, the difficulty to obtain authorization for a hospital bed or the lengthy wait to be forwarded for specific treatment should not be a reason for denying this care to elderly. Similarly, hospitalizations with the single purpose of avoiding death at the LTIE would not be an acceptable argument. Institutions need, in addition to better integration between the teams, a group reflection about palliative care, and about death and dying. Also concerning this aspect, it was observed that the decision about hospitalization usually includes an ethical dilemma concerning the actual possibilities of care and health recuperation:

of course we think: will it be better? Will they take good care of him? Will he be comfortable? Will they provide a comfortable bed, food? Because the hospital also lacks professionals. (D1)

While stating the conflicts and dilemmas, the directors did not mention the elderly's autonomy, which should be taken into consideration when making decisions, provided that they are capable of doing so, and become involved in the subject, to evaluate the possibilities and express their desire. Families should also be involved, especially when the elderly is unable to make his/her own decisions. However, when questioned, one director stated that families rarely decide in favor of or against hospitalization, leaving that decision for the LTIE to make.

\section{FINAL CONSIDERATIONS}

Communications between the LTIE and the health system occur against a background of disregard for institutionalized elderly as residents of the area covered by basic healthcare services. LTIEs are made responsible for the healthcare, with the resonance of excluding elderly from health program actions. On the other hand, LTIEs lack knowledge regarding the 
health system. Clarity regarding services, referral and contra-referral processes - forwarding processes, possibilities and encouragement by proposing alternatives can result in more successful structural bonding. It appears that both are unavailable or, using Luhmann's language, there is low sensitivity to dialogue and deepen collaborative actions based on existing healthcare projects and policies.

As a resonance of the noise produced by the communication between the health system and LTIEs, it is possible to identify ethical dilemmas in the health care provided to institutionalized elderly, which nonetheless seem to need further discussion regarding both the institution and gerontology domains.
Despite the successful encouragement of Luhmann's theory for LTIEs analyses, it is understood that the self-referential social systems theory does not have the purpose of being either the only or the best alternative. Rather, it has special attitudes for this task. Hence, from the perspective of the need for continuous research, applying Luhmann's systems in the analysis of the LTIE-Health System relationship, including system members, could promote even greater deepening regarding structural bonding. This analysis could constitute important support for the implementation of strategies to expand LTIE inclusion networks and the commitment of health services with institutions.

\section{REFERENCES}

1. Camarano AA. Brazilian population ageing: differences in well-being by rural and urban areas. IPEA. Texto para discussão [serial online] 2002 Mai [cited 2004 Mar 7]; (878):[33 screens] Available from: http://www.ipea.gov.br. 2. Senado Federal (BR). Lei n. 8.842, de 4 de janeiro de 1994: dispõe sobre a Política Nacional do Idoso. Brasília (DF); 1997. 3. Vieira EB. Instituições geriátricas. Avanço ou retrocesso?. Rio de Janeiro: Revinter; 2003.

4. Luhmann N. Soziale systeme: Grundriâ einer allgemeinen Theorie. Frankfurt: Suhrkamp; 1984.

5. Ojeda BS. A tecedura das relações saber-poder em saúde: matizes de saberes e verdades [tese]. Porto Alegre: PUCRS, Faculdade de Psicologia; 2004.

6. Teixeira CF, Paim JS, Vilasboas AL. SUS, modelos assistenciais e vigilância da saúde. Inf Epidemiol SUS 1998 abril-junho;7(2):2-25.

7. Moraes R. Análise de Conteúdo: limites e possibilidades. In: Engers ME, organizadora. Paradigmas e metodologias de pesquisa em educação. Porto Alegre: EDIPUCRS; 1994.

8. Yamamoto A, Diogo MJD. Os idosos e as instituições asilares do município de Campinas. Rev Latino-am Enfermagem 2002 setembro-outubro;10(5):660-6.

9. Agência Nacional de Vigilância Sanitária. RDC no 283, de 26 de setembro de 2005. Regulamento técnico para o funcionamento das instituições de longa permanência para idosos. Brasília: ANVISA; 2005.

10. Herédia VBM, Cortelletti IA, Casara MB. Institucionalização do idoso. In: Cortelletti IA, Casara MB, Herédia VBM, organizadoras. Idoso asilado: um estudo gerontológico. Caxias do Sul (RS): Educs, Edipucrs; 2004. 11. Mazo GZ, Benedetti TB. Rev Ciências Saúde 1999 janeiro;18(1):51-6.

12. Davim RMB, Torres GV, Dantas SMM, Lima VM. Estudo com idosos de instituições asilares no município de $\operatorname{Natal}(R N)$ : características socioeconômicas e de saúde. Rev Latino-am Enfermagem 2004 maio-junho;12(3):518-24.
13. Duarte MJRS. Atenção ao idoso: um problema de saúde pública e de enfermagem. Rev Enf UERJ 1994 maio; 2(1):10011.

14. Creutzberg M, Santos BRL. Famílias cuidadoras de pessoa idosa: relação com instituições sociais e de saúde. Rev Bras Enfermagem 2003 novembro-dezembro; 56(6):624-9.

15. Alvarenga MRM, Mendes MM. O perfil das readmissões de idosos num hospital geral de Marília(SP). Rev Latino-am Enfermagem 2003 maio-junho; 11(3):305-11. 